\title{
O slawie Maryny Mniszchówny. Dumna wojewodzianka jako nieustająca inspiracja
}

Elwira Buszewicz 


\section{Elwira Buszewicz}

\section{O sławie Maryny Mniszchówny. Dumna wojewodzianka jako nieustająca inspiracja}

\section{Intrygująca osobistość}

$\mathrm{P}$ ostać Maryny Mniszchówny zmusza do refleksji. Malo jest opracowań listorycznych bądź historycznoliterackich, zatrącających o krwawe i smutne czasy l yymitriad, których autorzy nie czuliby się zobowiązani do bodaj krótkiego komentarza opiniodawczego bądź opiniotwórczego. Przykladem chlodnej i zwięzlej relacji, pozbawionej jakiegokolwiek osądu psychologiczno-moralnego może być hasło biograficzne z wydawanej w latach sześćdziesiątych ubieglego stulecia Wickiej Encyklopedii Pouszechnej PUN $\mathrm{N}^{1}$. W biogranie tym brak emocji, ale mówią fakty; nader szczupla notka pokazuje dowodnie, ze tryumfy swej fortuny kobieta ta nieraz okupić musiała utratą wolności oraz śmiercią tych, których los na jej drodze postawil. Szerszy z konieczności biogram Jana Dzięgielewskiegow Polskim stoumiku biograficz"ymm pokazıje Marynę historyczną i Marynę legendarną. Najpierw, stwierdza autor życiorysu, „różnojęzyczne relacje z okresu tzw. 'smuty', panegiryki powstale z okazji wesela i plotka rozslawiły Marynę wśród wspólczesnych" "2, potem stala się ona bohaterka „bylin rosyjskich, licznych przeciętnych dramatów i powieści historycznych oraz romansów". Possód pisarzy sięgających po temat Maryny wymienia autor biogramu między inmymi Zofiç Kossak i jej Zlota

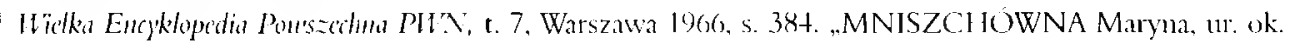

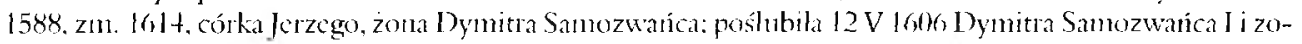
stala ukoronowana w Moskwic na carową; po zamordowaniu Samozwańca l tuwiçziona wraz z ojcem w Jaroslawiu nad Wolga: po odzyskaniu woluości udala siç 16018 do Tuszyna. gdzic uzuala 1)ymitra Samozuanica II za swego męża: po jego zanordowaniu przchywaha krótko w wiçzicniu; wraz ze swym kochankiom Kozakiem Iwanem Zarndzkim próbow:la bronić praw do tromu carskicgo: schwytana przez zwolenników Michala Romanowa, zıılarla w więzicniı".

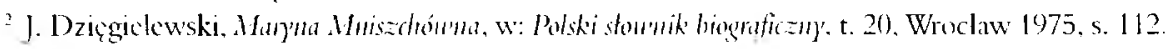


u'olnošc, Lopego de Vega i jego dramat El Gram Duque de Moscovia y Emperador perseguido (., chyba przeciętny" - komentuje z wahaniem), Fryderyka Schillera i jego niedokończoną sztukç Demetrios oraz oczywiście Aleksandra Puszkma i jego Borysa Godnnou'a, inspirację znanej w calym świecie opery Modesta Musorgskiego. Analiza danych prowokiuje autora do konkluzji:

Po odrzuceniu literackiej legendy, będącej wyrazem fascynacji niezwykłością biografii, pozostaje obraz kobiety dunnnej, obdarzonej wybujałą, a przerastająca ją ambicją i żądncj wladzy".

Musimy tu ze swej strony dodać, że równiez to, co autor nazywa literacką legendą, nieraz taki obraz utrwala, zaś badacze historii czy literatury mniej czy bard ziej świadomie prowokıją emocje i powotują do życia nowe legendy.

Czy slawa Maryny Mniszchówny pozostala żywa? Dla niektórych, wydawaloby się, umarła, a jeśli pozostały jeszcze jakiés jej ślady, to nie warto się nią zajmować. Wladysław Kopaliński w Stou'niku mitóu' i trady gi kultury ma tylko hasto Dymitr Samozu'aniec. Nie umieścil również postaci Maryny w żadnym kontekście w swojej Enckklopedii dnugiej ptrit. Nie tylko nie ma tu obszerniejszej o niej wzmianki; nawet w indeksic osobowym na stosownym miejscu jest jedynie autorka Trędouatej. Darmo szukalibyśmy tu nazwiska tej, którą świat nazywa czçsto „wielką awanturnicą niespokojnego czasu” i której cień ożywa w najmniej oczekiwanych okolicznościach. Zmarła w 1974 r. gwiazda rosyjskiej opery, Maria Maksakowa, odtwarzała tę postać w Borysie Godmmonie, co milośnicy jej sztuki komentowali słowami: „Gdy się na nią patrzy, można zrozumié, że z kobietą taką jak ona zbiegly muich mógl z latwością zostać księciem". O trwałości slawy Maryny Mniszclıówny przckonany jest także profesor Tadeusz Ulewicz. W jednym z tekstów publikowanych w "Terminusie” zdecydowal siç on wyrazić od dawna pielęgnowaną opinię dotyczącą frywolnej zagadki, mianowicie przystowiowego „od niepamiętnych czasów" zwrotu z mówieniem o pewnej części ciala Maryni. Sugestia Profesora jest następująca:

Wolno zaryzykować domyst, żc chodzito prawdopodobnic o slynną ongiś Marynę Mniszchównę. O nieciekawą przedniotowo, anbitną i żądną waadzy (choć, po ludzku, może nawet i żałosma) córkę tak samo nieciekawego ojca, wojewody sandomierskicgo, i żonę dwóch koniunkturalnych, kolejno po sobie następujących carów-samozwańców, o której rozprawiać u nas musiano tak szeroko i dosadnie, jak o zadnej chyba damulce z czasów przedrozbiorowych. Poszlaką zaś uboczną byłoby przy tym samo imię Maryni. Nie Marii zatem ani

\footnotetext{
"Hidem. s. 113.

${ }^{+}$W. Kopalinski. Encyklopedia drugicj pti. Warszawa 1995.

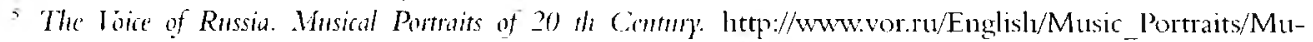

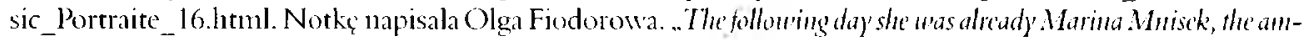

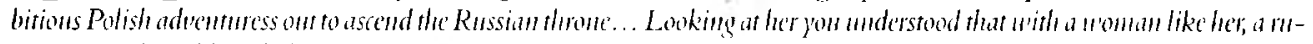

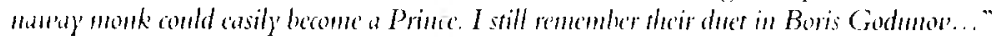


zdrobniale Marysi, gdyz nadawanie dziewczętom tego praktycznie imienia uchodzilo u nas wówczas ciagrle za nictakt, na wpól za bluźnierstwo".

Niektórzy historycy literatury uznają wprawdzie taką hipotezę za niepoważną, jednak zamieszczona wyżej wypowiedź, z jednej strony podkreślając rolę intuicji w badaniach kulturoznawczych i filologicznych, wydaje się także świadectwem dociekliwej postawy uczonego męża, który - jeśli wolno nam tu odnieść do spraw bardzo świeckich postulat biblijnego męedrca, Syracydesa -

Przypowieści mężów zawołanych będzic zachowywal a subtelności przypowieści wespól doścignie. Tajemnic przypowieści badać się będzie, a w skrytych podobieństwach obierać się będzie (Syr 39, 2-3).

Badanic „skrytych podobicnistw” będzie równicż noim przesłanienn na użytek niniejszej wypowiedzi.

Warto zauwazyć, żc zacytowana powyżej opinia profesora Ulewicza zawicra w sobic mate kompendium rozbieznych opinii o naszej bohaterce. $Z$ jednej strony bowiem nazwanie jej „nieciekawą przedmiotowo” figurą odbija przekonania niektórych wspólczesnych oraz potommych, że ta postacią, która wniosła do naszej historii więcej złego niz dobrego, zajmować się nie warto. Z drugiej strony, podkreśla siç̨, ż sprawa Maryny, o której dyskutowano „dosadnie", ma w sobie nieco pikanterii. Z trzeciej strony widzi się jej zbieżność z modelem bohaterki tragicznej, czy to jako politowania godnej ofiary, czy też - częścicj-zdecydowanego i ambitnego podmiotı. Z kolei wzmianka o "slynnej niegdys”" bohaterce każe przywodzić na myśl literaturę okolicznościowo-panegiryczną, którcj echa możeny potem odnaleźć w późniejszej tak zwanej literaturze pięknej, co moze wzbudzić w nas pytanie o nie do końca odkryte funkcje i sensy literatury okolicznościowej i użytkowcj, której życie objawia siç niekiedy w przedziwnych okolicznościach.

\section{2. „Nieciekawa przedmiotowo...”}

Taka postawa względem postaci Maryny oznacza często ukrytą (albo wcale jawną) niechęć. Za jej patrona możony uznać Stanislawa Źólkiewskiego, który w swym pamiętniku wojny moskiewskiej z wyważonym pietyzmem ksztaltował wizcrunek swego czasu i ówczesnych graczy na polityczncj scenie. Cizytając Poczatek i progres wojny moskieu'skiej, odnosi się wrażenie, że pan hetman najchętniej nie wymieniałby imienia dumnej wojewodzianki. Swiadectwem takiej troski może być otwierająca tekst jednoznaczna refleksja nad polityczną rolą Jerzego Mniszcha, nazwanego tu niemal wprost czlowiekiem małym, podlym i nikczemuym, a zupelnie otwarcie zaślepionym, chciwym i pysznym ${ }^{7}$. O roli, jaką odegrała w całej sprawie

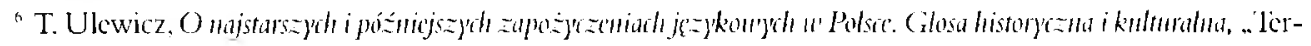
mintes". R. II (20)(6)), z. 1-2, Kraków 20(0)0, s. 26.

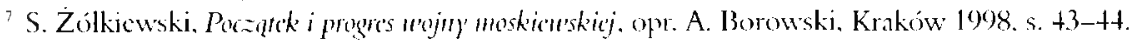


Mniszchówna, ani słowa. Nawet gdy w'spomina o malżeństwie Łże-Dymitra z Maryną, nie wymienia jej imienia, raczej deliberując nad obrotami Fortuny:

Toczyla się tragedia: wesele w Krakowie z pompa, droga do Moskwy na kotczych, na karetach z okrutnym orszakiem [panów szlachty polskich] i bialych glów. Wesele się odprawiło, a zaraz w kilka dni szalbierza zabito i naszym się dostato, i wstydowi bialoglowskicmu nic przepuszczono ${ }^{k}$.

Osoba Maryny zaczyna się rysować "Zólkiewskiego bardziej konkretnie, gdy na scenę dziejów wkracza drugi Dymitr, „do pierwszego w niczym (oprócz żc czlowiek) — jak wymownie stwierdza pan hetman - nicpodobny". Wówczas Żólkiewski kilkoma pociągnięciami pióra kreśli lapidarny, lecz znaczący wizerunek niewiasty, „której się bardzo chciało carować". Trzecia odstona z Maryną w roli ghównej ujawnia otwartą pogardę hetmana, a także chyba osobistą ansę względen osoby, która wzgardziła jego dyplomatyczną misją:

jako była niewiasta ambitiosa, grubo dosyć blekotata: „Niech też król jegomość ustapi carowi jegomości Krakowa, a car jegomość da królowi jegomości Warszawę".

Dosadność tej naracji i zacytowana wypowiedź nie wymagają dodatkowych komentarzy. Chyba nigdy w ciągu całej opowieści moskiewskiej nie zszedł pan hetman w tak niskie rejestry stylistyczne.

\section{3. ,Szeroko i dosadnie..."}

Niewiasta scharakteryzowana przez Zółkiewskiego jako ambitiosa dbała także o swą dobrą slawę, więc teoria pareniologiczna profesora Ulewicza nie ucieszylaby jej. Cytowane przez historyków zajmujących siç biografiami Sanızwańca bądź Maryıy fragmenty jej listów potwierdzają to wyraźnie. Przyznawała ona:

Zalu pelne serce, że i na slawę ıczciwą i dostojność, od Boga daną, następują. Z niepoczciwymi mnie zrównali na posiedzeniach i bankietach swoich, przy kuflu i trunkach wspominali" ${ }^{11}$.

Gencza „szerokiego i dosadnego” rozprawiania wydaje się zatem woale starodawna. Komentarze, zwlaszcza męskie, na temat Mniszchówny jako osoby robiącej karierę glównie przy pomocy pewnej części ciała, nie mogly być zjawiskiem odosobnionym. Przetrwaly onc i do dzisiejszych czasów. Jakkolwiek cierpnie mi skóra na myśl o tym, że miałabym tu zacytować pismo, którego z zasady nie czytuję, a którego tytułem jest przeczenie, uczynić to chyba

"Ibidem, s. $\overline{5}$ ().

"Ibidem, s. 52.

1" A. Hirschberg, Majpha Mniszdhoma, Inow 1927. s. 177. 
muszę. Krzysztof Pilawski, autor artykułu o wdzięcznym tytule Żegnaj Gienia śmiat się zmicnia, wlaśnie Maryną Mniszchówną otwiera poczet sylwetek Polek, które przelotnic lub na dhużej gościły w łożnicach Rosjan, a dziçki temu nierzadko zdobyły większą popularnośćl . Cokolwiek rzec o dość swobodnym stylistycznie tekście, przynosi on międ zy innymi ciekawe informacje o sławie Maryny (nb. raczej zlej slawie) na ziemiach rosyjskich.

\section{Lud rosyjski nazywał ją Marynką Bezbożnicą, I Ieretyczką, Czarownicą. To ona wzbogacila język rosyjski o znane do tej pory określenie .dımma Polka”. [...] W zeszłym roku wydano powieść historyczną Iriny Molewej Mar'ma Mnizzed, car) Wazchlurusi ${ }^{12}$.}

Trudno powstrzymać siç od wrazennia, że podstawową inspiracją opinii i refleksji pokoleń byly jednak nie erotyczne perypetie naszej bohaterki, lecz bądź to jej nieszczęsny los, bądź jej nieumiarkowane aspiracje i duma. Jak syntetycznie i zwięźle ująl to Aleksander Hirschberg, autor obszerncj biografii, do dziś przywoływancj przez historyków i filologów, popularyzatorów dzicjów i edytorów źródel, przekonanie o własnej wyższości uwydatnia się w korespondencji Maryny. W pewnym micjscu swej narracji autor zacytował nawet ponownie niektóre fragmenty listów, czyniąc swoisty tematologiczny ekscerpt. Wszystko tu się ze sobą zgadza. Otrzymujemy portret osoby, która „wolalaby śmicré, niż żeby świat miał więcej z nieszczęścia jej triumfować” i która „będąc panią narodów, carową moskiewską, nie może być znowu poddanką i wrócić się do stanı szlachcianki polskiej" ${ }^{13}$. Tę zadziwiająco dobitnie sprecyzowana samoświadomość potwierdza także wpis Maryny do Krięgi królewskiej biblioteki Akademii Krakowskiej. Na wpis ten zwraca uwage l)anuta Czerska, autorka biografii Dymitra:

Ze wzruszeniem, zrozıniałym dla każdego historyka, patrzylam na kartę, na której w ozdobnych rankach widnieje napis: ,Maryna carowa Moskiewska rękę wlasną" "1+.

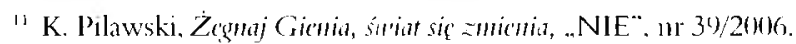

12 Ibidem. Powiéści Iriny Molewej nic wynienia jeszcze bogaty przedmiotowo. zwhaszcza w kontekścic trady-

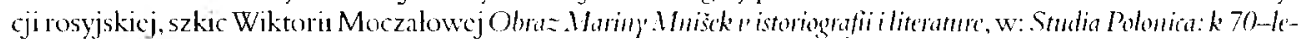
tin I iktora. Aleksandrowiăa Horen. Moskva 20102, s. 372-397. W szkicu tym zyskala też szersze naświctlenic wizja Maryny jako „wiedźny”. .heretyczki“ czy „, bezboznicy”, njmowana z mucj u nas akcentowancj perspektywy wyznaniowej, nierzadko z uwzględnicniem rozmaitych .transgresji”. I tak w popularnych historycznyclı pieśniacl podkreśla siç niczgodność obyczajow Samozwańca z prawoslawna tradycją: gdy wszyscy kniaziowic i hojarzy modlą siç w cerkwi. .. Griszka-rozstryżka” kapie się w laźni, pojmowanej tu jako locus profamus, ideowe przcciwienstwo cerkwi (por. s. 376). W historyczncj powieści M. Zagoskina Jurij Mitostauskij (1829) Samozwanticc ukazany jest jako opçtany i prokliany”, a Maryma - jako wiedźna, która „nadal lata kolo Moskwy” (co budzi nicjakie zdumicnic prowadzacych dialog bolıterow bo przecicż urodzila siç ona w Polsce. a powszechnie wiadomo. że wszystkic wiedźny pochodzą z Kijowa [sic!| (tamżc. s. 376). Symbolicznym znakicm tej transgresji, a zarazen swoistyn sighmm Maryny jako bolıterki tragicznej. jest podkreślany we wspólczesnycl relacjach akt przchrania siç Maryny w niestossowną szate - czy tor strój moçski dojazdy konnej, czy tez ,polska” a nic "rosyjską" sukniç. Jak zanważa Moczalowa (s. 385), semantycznie oznacza to przekroczenic nomyy spoleczncj lub narodowej.

${ }^{13}$ A. Hirschberg. op. cit.. s. 338.

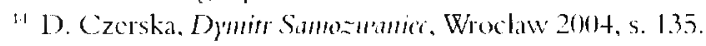


Chodzi tu naturalnje o wzruszenie wynikające z dotykalnego doświadczenia postaci historycznej za pośrednictwem dokumentu. Postać Maryny budziła jednak często wzruszenia po prostu ludzkic. Ona sama przyczynila się do utrwalenia takiego swego wizerunku pamiętnymi słowami: "Jeślić kimś na świecie, tedy pewnie mną szczęście okrutnie poigrywalo" Czy Maryna byla igraszką Fortuny, czy ofiarą wlasnej ambicji? Marionetką przetargową w rękach ojca, czy świadomyın reżyserem dramatu? Te pytania nieustammie zapladniaja dociekliwość i inwencję zarówno autorów literatury naukowej czy popularnej. jak i klasyków literatury pięknej.

\section{4. „Po ludzku, może nawet i żałosna...}

Nie miejsce to, by szerzej tu omawiać utwory literackic, którc czynią z Maryny główną bądź przynajmniej poboczną bohaterkę narracji czy dramatu. Warto jednak pokazać, w jaki sposób pisarze korzystali ze źródel i zastanowić się, dlaczego nie mogli uwolnić się od emocji. Nie tylko beletrystom, jak zaraz zobaczymy, trudno bylo uwolnić się od emocji. Zygmunt Krasiniski daje w Agaj-Hanie' wizerunek Maryny podporządkowany wizji bohatera romantycznego. Jest to monumentalna dumna pani. pelıa dostojnego piękna, lecz cierpieniem zasługująca na litość Królowej Niebieskiej i na życie wieczne w nicbic. Żaden chyba z polskich pisarzy nie okazal jej tyle szacunku:

Królowo Polski! daj jej zasiąść u stóp Twoich. bo korona carów byla dla niej wieńcen cierniowym, życic całe dluga pielgrzymką. daleko od ojczyzny, wśród obcych i zawistnych. Królowo Polski, zlitıj siç nad córą Twoją! ${ }^{16}$.

Krasiński kończy los Maryny tragiczną śmiercią utopionej pod lodem, idąc za wersją utrwaloną przez Juliana Ursyna Niemcewicza. I Historycy za bardziej prawdopodobny uznają raczej przekaz o śmierci nieszczęsnej imperatorowej w więzieniı w Kołomnie. Tę wersję popularyzowal Zygmunt Charlewski, autor krótkiego, opartego przede wszystkim na Hirschbergu szkicu biograficznego Dumma wojewodzianka, wydanego w Biblioteczce Historyczno-Geograficznej "Roju”, której przyświecało niewątpliwie budujące hasło „Nie kłanać — bawiąc, nié nudzić — "cząc" ${ }^{17}$. W konkluzji swej broszurki autor sktania czytelnika do refleksji geograficzno-sentymentalnej, przywołując wieżę w Kolomnie, zwaną i wówczas, i dzisiaj, „Marinkina basznia”:

Cierpliwy Czytelniku, jeśli w swej wędrówce przez życie zabłądziłbyś kiedy do Kolomny, zapytaj o Marynı̨ Mniszchównę̧ [...] Tu pokutowała Maryna Mniszkówna ${ }^{18}$.

\footnotetext{
1. A. Hirschberg, op. cit.. s. 3.37.

${ }^{16}$ Z. Krasiński. Aguj-Llan, Krakow 20)(2, s. 1 +0.

1? Z. Charlewski, Dumma wojemodzianka, Warszawa 1936. Biblioteczka Historyczno-Geograficzna „Roju”. Cykl: .,Wladcy". Nr $2+8$.

${ }^{18}$ Ilidem, s. 39.
} 
Popularyzatorowi wicdzy historycznej obce sa emocje Krasińskiego. Widzi w Marynie ofiare pychy ojca. Zaprawia swa narracje komentarzami o charakterze melodramatycznych uniesień, których prawdopodobnie nie powstydzilaby się sama wzmiankowana tu już I Ieléna Mniszek. Pozwolę sobie rzucić garść przykładów:

W kazdym razie Maryna musiała się podobać. Jej wiośniana uroda, jakkolwiek nieklasyczıa, mogla wywrzeć na młodzienicu duze wrażenie już po pierwszym widzeniu przelotnym. Szczególnie jej ogromme, ciemne oczy pozostawialy niezatarte wrażenie";

Gdybyż nieszczęsna wiedziała, iloma lzami będzie musiala okupić każdą perlę! $!^{\text {?n}}$

Za cóz tyle cierpień, za cóz taki okrutny wyrok losu? Za wolę chciwego ojca, który ciało młodziutkiego dziewczęcia sprzedal szalbierzom za nędzne srebrniki, który rozwijający się dopiero kwiat-duszę zatrul jaden szalonej ambicji i dumy' 21 .

Charlewski nie czytal najprawdopodobniej niedokończonego dramatu Schillera Deme-

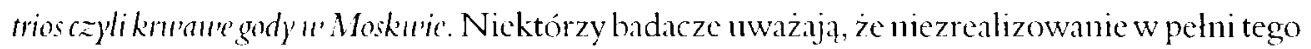
dzieła jest dla literatury wielką stratą. Edytor angielskiego przekładu tego dzieła stwierdza z szacuukiem:

Nearly enenticth century treatment of the theme by Paul Ernst has only shight valuc. Prosper Meriméce created a Frend Denitri-play of moderate sncess, while Pushkin's blank verse drama of 1827, landmark that it is in Russian literature, is neither Pushkin's greatest work nor the fullest treatment of the subject. Mussorgski's opera, Boris Godmon, which had its premiere in 1874, follow's Pushkin's play in part, and, like it, is really' concenced, not with Dmitri, but uith his opponem. The same qualification applies to the imposing trilogy of eerse-plays by A. K. Tolstoi: The Death of Ivan the Terrible (1866), Tsar Fyodor Ivanovich (1868), and Tsar Boris (1870). In all Russian ver-

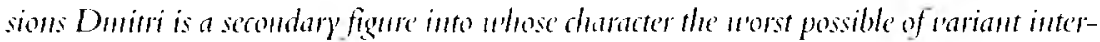
pretations is read. His story, in the nobh' tragic terms proposed by' Solliller, still an'aits the hand of a great dramatist ${ }^{2-}$.

${ }^{14}$ Hidem. s. 21.

It Ilidem, s. 25.

$\because$ Ibidem, s. 58 .

"Ch. E. Passage, wstęp w: F. Schiller, The Bride of Messima: Or, the Enomy Brothers, a Tragedy' with Chornses. Whil-

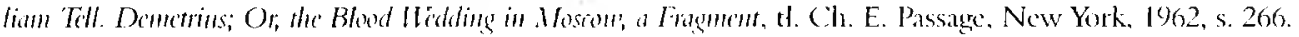
I. Nicmal już dwudzjestowiecznc ujęcic tematu przez Paula Enısta posiada jedynic nicwiclką wartość. Prosper Mcrinéc stworzyl - z uniarkowanym powodzcuicm - francuską sztukį o Dymitrzc. podczas gdy Puszkinowski dramat z 1827 r., napisany bialym wierszenn. reprezentacyjny w literaturze rosyjskiej, nie jest ani najwiçkszym dzickem Puszzkina. ani najpehncjszym ujęciem tematu. Opera Musorgskiego, Borys Godhmow, mająca swa premicrę w 1874 r..czçściowo podąża za szztukią Puszkina. i. podobnic jak ona. dotyczy w istocie nie Dymitra, lecz jego przeciwnika. Takia sama kwalitikacja stostje sic do imponujacej trylogii dranatycznej wierszem 
Co uderza w dziele Schillera, to konsekwencja i upór Maryny, która z całą świadomością uczestnictwa w politycznym szalbierstwie i bez cienia tkliwości względem pierwszego Dymitra rozgrywa swą intrygę władzy. To ona rządzi ojcem, a nie on nią. Jest apodyktyczna i bezwzględna. Nie ma szacunkı do uczciwej polskicj szlachty, nawet o wielkich nazwiskach ${ }^{23}$. Jest jednak postacią bardzo interesująca. Autor ksztaltuje jej wizerunek zgodnie z dostępıymi sobie przekazami historycznymi, lecz daje też pole wlasnym domysłom i intuicji, każącej przypuszczać jak - jego zdaniem - musialo być, chociaż historia tego nie notuje ${ }^{2+}$. W ten sposób uzyskujemy wizerunek Maryny godnej wspólczucia jedynie jako bohaterki tragicznej, poniekąd ofiary snu o wlasnej wielkości. Podobną opinię, co cickawe, wyraził Hirschberg w swej wciąż instruktywnej i fundamentalnej biografii:

Tak więc żądza wladzy i panowania była najwybitniejszym, dominującym rysem w jej charakterze. Z tego tez powodu zostala po kolei małzonka dwóch szalbierzy, a w końcu nawet kochanka, czy też zona atamana Zarudzkiego. Z upadkiem Zarudzkiego i dumną wojewodziankę straszna dosięgła kara. Nie igraszka losu więc, jak uskarżała się w zaślepienniı swoim, lecz przede wszystkim ofiarą wlasnej ambicji była Maryna ${ }^{25}$.

\section{5. „Niegdyś sławna...”}

Bogata literatura okolicznościowa utrwaliła efemeryczną slawę Maryny Mniszchówny. Mamy tu do dyspozycji wielokrotnie wydawane, wznawiane i cytowane diariusze, relacje,

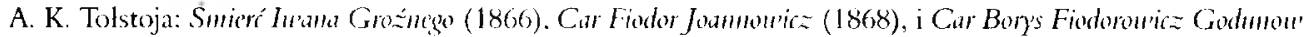
(1870). We wszystkich wersjach rosyjskich Dyınitr jest dnugorzęd ną figurą. w której charakter wpisuje się najgorsza z mozliwych różnych interpretacji. Jego historia opiewana szlachctnym, tragicznym językiem zaproponowanym przez Schillera wciąż oczckuje ręki dobrego dranaturga"]. Jeszcze cickawsza wydaje siç uwaga inicjalna na s. 259 kegoż wstępu, sugerująca. iz fragment sztuki Schillera Demetrins jest czystym diamentem, który jaśnicje w panięci, podczas gdy pewne dokończone drannaty; równiez samego Schillera, zostaly zaponnnane.

${ }^{23}$ Por. zwl. akt I. scena 2: tamzes. 296 (w wersji angiclskiej):

MARYNA: It7o are these people? The' are common riff-ratt.

ZAMOSKY: I tum the Castellan of I ilma's cook.

OSSOLINSKY: We're stuble humds of the Stanos of $/ \ldots$ /

OPALINSKY: And l'm his corthmant.

BIELSKY: I'm his turn-spit lad.

MARYNA: Fic, Odou'alsky!' 'These' are really' too base!

STABLE HANIDS: Whe we Piasts and fret-inom Polish men.

Do not confiuse as urith low' peasant trash,

We're men of quality, we have our rights!

ODOWALSKY: Yes, they recite the ir whippings an a arpet.

ZAMOSKY: Do not despise us, we hale woble hearts.

ODOWALSKY: Enlist them, give them foots and horses. The'

Will fight their way through with the best of thent.

MARYNA: Go!

And come bade when you book like human beings.

My stcurad urill distribute clothing o jout.

${ }^{2}$ Por. Ch. E. Passage, op. cit.. s. $26 t$.

${ }^{2}$ A. Hirscluberg. op. cit.. s. 338-339. 
poselstwa i listy, a także dość obtitą poezję okolicznościowo-polityczną. Tę ostatnią skomentował już dość szeroko Juliusz Nowak-1)lużwski. Ustalenia jego można by naprędce zrekapitulować następująco: Poset moskien'ski nadwornego chwalcy Mniszchów, Jana Żabczyca, gładki, choć oklepany i nudny z powodı spowszedniatych schematów panegirycznych. Maryna jest tu wcieleniem wszelkich cnót, równa Junonie i rzynskiej Lukrecji. Lepsze — zdaniem badacza - Zegnami Ojczyzm) móncj cesarzoncj moskicuskicj, oparte na retorycznym schemacie listu pozegnalnego, a takze Winszouranic Polski, parenetyczna adhortacja dla carowej. Warto podkreślić, ze 1) luzewski - co nietypowe dla filologa jego czasów — odważa się naruszać stereotypy mówienia o poezji pancgirycznej i nie widzi „błędu” pocty w tym, że jego „doskonalej Marynie” brakuje ,repliki w rzeczywistości, w postaci notorycznie pyszncj i dumnej listorycznej Maryny" "2n.

Pieśni ma fest wicszn)' (w dwóch redakcjach) Stanisława Grochowskiego traktuje Dłuzewski jako zdeterminowane politycznie i panegirycznie, ujęte w szerokiej perspektywie, poetycko wyksztalcone na dobrych wzorach, weale nie gorsze od dzieła Żabczyca ${ }^{27}$. Hymenemsz Jana Jurkowskiego uznano za dziwaczny - z calym biblijnyn i mitologicznym aparatem i wyobrażeniem bogiń świçtujących na weselu w Krakowie. Wenus (jak chce Dłuzewski, „generalna rajfurka wszystkich poetów") obdarowıje tu I yınitra nową nitką Ariadıry, która ma go doprowadzić na dwór pięknej Maryny ${ }^{2 *}$. Sebastianowi Lifftelowi i jego Godon moskien'skim dostaje się dosyć ambiwalentna ocena - może i od strony literackicj. jak chee Waclaw Aleksander Maciejowski, , licha ranota”, ale za to , udany utwór beletrystyczny”, ciekawy w szczególach, raczej budzący zainteresowanie hodoeporikon niż epitalamium" . Spośród poetów rokoszowych najciekawszy Daniecki, malıjący jedıak raczej konterfekty l)ymitra i Mniszcha niż Maryny ${ }^{3 i 1}$. Whadysławiusz - elegijny i szczery, mija sic̨ z prawdą historyczną w wizerunku Maryny jako pokonnej dziewczyıy, bo komponuje , według własnej wizji "31. Interesujące wydają się Dłuzewskiemu - bo mogą być w istocie - anonimowé utwory okresu Dymitriad, a zwlaszcza Pieśi dziesiąa z Dzu'onka serdeczu'go (1620), bẹdąca w gruncie rzeczy ostrzezeniem dla triumfującej Maryny i wezwaniem jej do lepszej baczności ${ }^{32}$.

Ogólnie rzecz biorąc, odnosi się wrażenic, żc Dlużcwski, obalając pewne stereotypy myślenia o litcraturze okolicznościowej, uksztaltowal też nowe, które już nieco skostnialy i domagają się rewizji ${ }^{33}$. Wydaje się to jednak pobudką ku obszerniejszemu dziełu, zorientowane-

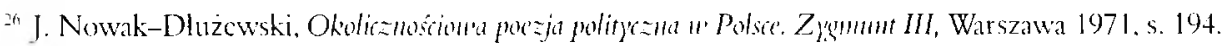

Ihidem, s. $195-196$.

$2 \times$ Ibidcm. s. 196.

29 Ilidem. s. 197.

(1) Hidem. s. 198-190.

Hhidem. s. 202 .

"Mide'm, s. 205.

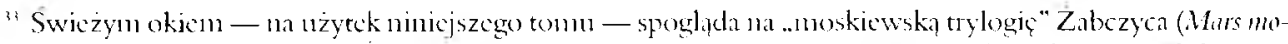

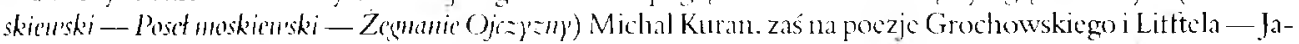
cok Wójcicki. Być moze warto uczynić to także w odniesieniu do jurkowskicgo i innycl. Byé nnoze przydatoby siç krytyczne spojrzenic na wszysthic utwory zcbrance w edycji Teodora Wicrzbowshiego Smmonge u'viemia 
mu nie tyle na "stawç Maryny”, co na konwencje i wartości okolicznościowej poezji zwiazzanej z dobą Dymitriad.

Badanie okolicznościowych materialów dotyczących owego czasu przynosi znamienną refleksję. O ile diariusze, poselstwa i imme relacje akcentuya przcde wszystkim przcpych, paradność, pompę i bogactwo tak krakowskiego, jak moskiewskiego świçtowania breve regnnm Maryny $^{3+}$, o tyle poezja panegiryczna wpisuje jcj postać w pewien idealny plan polityczny i gratuluje jej uśmiechu Fortuny. Widzimy to zwlaszczal w utworach Grochowskiego, który kończy epigramatyczny konterfekt Mniszchówny znamienmą pointą:

Jedną taką z tysiąca szczęście gdy ujrzalo, Zdumiawszy się, carową wielką ją mieć chciało ${ }^{35}$.

Rysując przed świezo upieczoną hosudarynią obraz prześwietnego whadztwa w północnej Arkadii, nie mógl być chyba nieświadom obrazu "grubej Moskwy”, kreślonego - począwszy choćby od Eliasza Piclgrzymowskiego ${ }^{31}$ - raczej w ciemnych barwach. W świetle dostępnych źródeł obraz moskiewskiej rzeczywistości przedstawiał się późniejszym badaczom historii w taki sposób, ze popularyzator wiedzy mógł to wyrazić w dobie dwudziestolecia międzywojennego następującymi słowami:

W ogóle ludozerstwo w ówczesnej Rosji nalezało do codziennych, powszednich zjawisk. Dzieci zjadały rodziców, rodzice - dzieci, gospodarze — gości, oberżyści zabijali podróżnych i odwrotnie. Na targach sprzedawano po wygórowanych cenach drobno sickane i ugotowane w pierogach miçso ludzkie ${ }^{37}$.

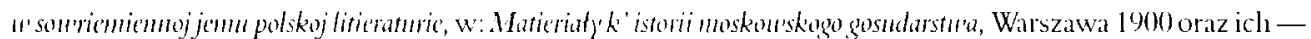
przynajmnicj cz̧̧ściowa - ponowna publikacja.

${ }^{3}$ Nie znaczy to że poezja jest pozbawiona tych akcentów. obficie zaznaczających się u Żabczyca czy Lifftcla.

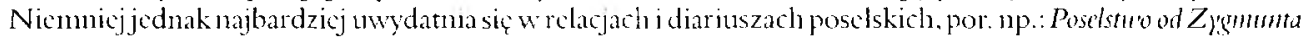

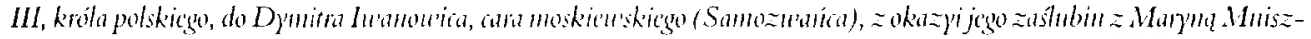
choum, opr. i wst. J. Byliniski. Wroclaw 20)2. Tu zwdaszcza np. opis wjazdu carowej do Moskwy z zaakcentowaniem przepychu paradnych powozów (s. 30 i mast.) albo koronacji Dymitra i Maryny: „car ubrany w szatç aksannimą czerwoną, kanieniani i perlani sadzoną tak gęsto, że malo co znać by lo aksanitu" (s. 45); „Carowa $[\ldots]$ w bociech skórzanych, perlanni laat towanych. Korong̨ przed nią niessiono na misie zlotej. Szatę na subie' miała z rękawami szerokimi, aksamitną czervoną. kosztowną bardzo, rubinami i perłani haftowaną" (s. 45). Por. tez wydany ustatnio na nowo. a znany weześnicj z edycji Hirsch herga, Stanistawa Nienojewskiego Dyja-

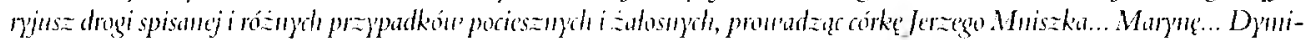

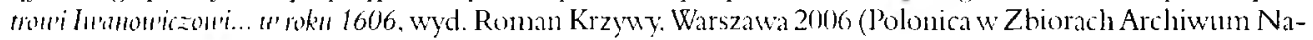
rodowego Szwecji. t. 4). s. 78: .. Potem hosudaryni szla po moskicwsku ubrana, w sukni po kostki, zfotoglowowcj. perlami haftowancj, w kowanych, czerwonych bociech". Interesujące, ze Niemojewski motywuje dlugotrwaly pobyt Dymitra w laźni rosyjskim przesądem religijnym (por. s. 81 ), al historycznc pieśn rosyjskic (o czym byla mowa w przypisic 12 ninicjszego tekstu) uważają to za niczgoduc zsacrum.

${ }^{3} \mathrm{~S}$. Groclowski. Hierser i imme pisma to precturasze, opr. K. J. Turowski, Kraków 1859. s. 118.

36 Diariusz legacji E. Piedgrzymuwskiego oraz jego wierszowana przeróbka Postlstu'o i króthie spisanie rozpan'y'

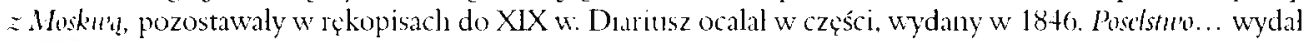
A. Brilckner w 1896.

3. Z. Charlewski, op. cit.. s. 10. 
Wspomniane przed chwilą Pieśni ma fest... Grochowskiego sa jednak interesujące nie tylko ze względu na aspekt propagandowy i kreację poetyckiego świata. Doczekały się one swoistej filologicznej oceny, zawartej immanentnie w innym dziele literackim: wielkiej, dramatycznej ,machinic historycznej” Adolfa Nowaczyńskicgo Car Samozuniec czlli polskic ma Mosku'ic go$d y^{34}$. Ocena twórczości okolicznościowej Stanisława Grochowskiego, z którego Pieśni na fest czyni autor swoisty centon, zostala zawarta juz we wstępnych didaskaliach .. Obrazı piątego":

W równym czasic z rozgwaru biesiadnego dobywa się mozolnie, w toku juz głośny panegirykus, czyli ,chwalne pienia”, recytowane wedle o. o. Jezuitów recepty: trybem uroczystym, kazalnym. Często hałas tłumi słowa bobkowancgo skrobiryma:

Zabrzmij tryumfie! Niewyslowionemu

Spiewajny wszyscy innieniu Pańskiemu!

Wydarte sobie Dymitr objął mocne

$$
\text { Brzegi pótnocne." }
$$

Dalej natomiast, w dialogu między Bassmanowem, Buczyńskim i Stadnickim, kwestia poezji okolicznościowej służy ukazaniu różnicy kulturowej miçdzy Polską a Moskwą:

BUCZYNSKI: [...] Oto na sarmackich ucztach zawzdy bywa bobkowany jakiś czlowiek, którego Kamoeny nlatej są ceny, rzeczom bieżącym wieczności nadaje swym dowcipem...

STAIONICKI: [...] Wielkich panów taski uciesznym rymem chwyta, jakoby rybitwą był... I Ialıa. $\left[\left.\ldots\right|^{+i !}\right.$

BUCZYNSKI: [... Karmen poety zapowiada siç coś tak dlugic, jako whoskic makarony... Haha...

STADNICKI (do Bassmanowa): Aleć was to cieszy nocści Bassman i bawi! [ . . I

BASSMANOW (wesolo): U nas tego nie znaja... To wielmi wesoly obyczaj!

BUCZYŃSKI: Bożez mily! Ile to 11 was obyczajów spólnycl światowi całemu nie znaja... Moc! Wielką moc! ${ }^{+1}$

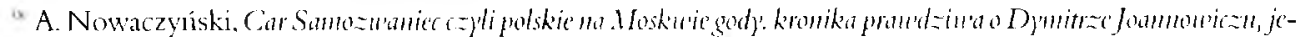

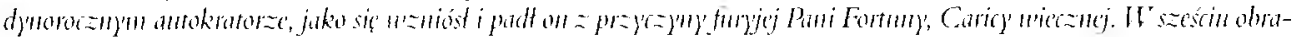

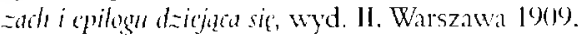

2.y Ibide'm, s. 212

4i) Ibidem, s. 213-21t.

" Ibidem, s. 215
} 
Opinia Nowaczyńskicgo może się wydawać niekiedy krzywdząca dla Grochowskiego, ale nic sposób unikną́ przekąsu, gdy trzeba się zmierzyć z takimi np. wersami rozpolitykowanego księdza-poety:

To dziś po wszysthim siviecie slawa szerzy,

Że z Wielkich Kończyc Polak Mniszech Jerzy,

W moskiewskie państwa, jako Bóg uradzil,

$$
\text { Cara wprowadzit }{ }^{+2} \text {. }
$$

Na przykladzie wierszy Grochowskiego sprecyzował Nowaczyński swoją ocenę poezji panegiryczno-okolicznościowej: zasadniczo jest nicwielkiej wartości i przydługa, niekiedy jednak... rozwesela, a poza tym utrwala w pamięci wieków chwile biczące oraz ich bohaterów. Z pewnościąjednak nie tylko na tej przestrzeni literatura przedziwnie splata się z życiem.

\section{Wieczne powroty pośród mrocznych dni}

Można odnaleźć cieni Maryny Mniszchówny nawet tan, gdzie z truden byśmy się go spodziewali. Trzeba w'tedy pomyśleć o powtarzającej siç na różne sposoby historii, o zdumiewających paralelach i ich przedziwnych odczytantach literackich. Anna Achmatowa poświęciła Marinic Cwietajewej wiersz Spóźniona odponieds, w którym wykorzystuje element krajobrazu Kolomny, jakim jest wieża Maryny, zbieźność imion Cwietajewej i Mniszchówny, a także pewne pokrewieństwo jej niedoli z tragicznym losem tej ostatniej ${ }^{+3}$. Maryna Mniszchówna, jak i Maryna Cwietajewa, są tu po prostu otiaranıi swych czasów, istotami nieszczęśliwymi, płacącymi za swą obecność na scenie politycznego dramatu.

\section{Анна Ахматова}

\section{Поздииі ответ}

\section{Lisemacroit}

\section{Белорученька моя, иернокнажница...}

Невидимка, двойник, пересмсшник, Что ты ирячешыся в черных кустах, То забьсшься в дырявый скворечннк, То мелькнешь на погибших крестах,

t2 S. Grochowski, op. cit., s. 1113 (Piesii I).

t. Siergicj Efron. wplątany przez radzieckic tajne sluzby w morderstwo zachodniego urzçdnika, ucickł do Związku Radzicckicgo. Dwa lata późnicj Cwictajcwa i jej syn podązyli za nim. lącząc się z Efroncm i córką po-

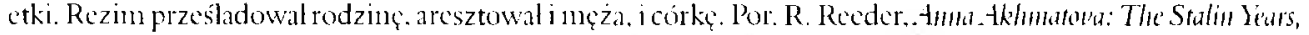
„New England Revicw”. Vol. 18. 1997. Wartododać. zc Cwictajewa sama utozsamiala siç w róznych wierszach z Maryną Mniszchówną. Zwracal na to równiez uwagę w swej poezji zafascynowany Cwietajewą Osip Mandelsztam. Por. W. Moczalowa. op. cit.. s. 372-373. 
То кричншь из Марннкиной башни:

„Л сегодня вернулась домой.

Полюбуйтесь, родимые пашни,

Что за это случнлось со мной.

Гоглотила любимых пучина,

И разрушен родитсльский дом".

Мы с тобою сегодня, Марнна.

I Іо столице полночной пдем,

А за нами таких миллионы,

И безмолвнее шествия нет,

А вокруг погрсбальные звоны,

да московские дикис стоны

Вьюги, наш заметаюшей след.

16. марпа 1940. Фонтанный Дом.

\section{Spóźniona odpowiedz ${ }^{++}$}

Moja Czamoksigziczeko o bialyde raczetad.

M. C.

Niewidzialna, jak trefniś bliźniacza.

W czarnych chaszczaclı się snujesz jak mgla:

Albo dziupla ukrywa cię szpacza,

Albo krzyż, który śmieré w sobie ma.

Wznosisz z wieży Maryny wołanie:

"1) ziś do domu wrócilan ja juz...

O, przygarnij ojczysty muic lanie,

Cóz się ze mmą teraz stalo, cóz?

Moi mili w otchlani, jak w grobic,

Dom rodzinny w ruinic, aclı, żal..."

Dziś, Maryno, wędruję przy tobie

Przez pólnocną stolicę gdzieś w dal.

A za nami sa takich miliony,

A ten marsz, jakze niema to rzecz...

A dokola pogrzebne brzmią dzwony

I jęk dziki, moskiewski, szalony,

Kiedy zamiéc nasz ślad zmiata precz.

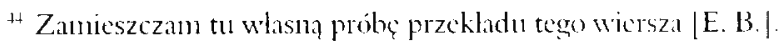


To nicoczckiwane utożsamienie może nam pozwolić na cliwilę zadumy nad poezją, która przerzuca mosty nad narodani i nad epokami historycznymi, każąc popatrzeć na dramaty ludzkic jako na nieodłączną implikację uwiklań ludzkich cywilizacji, znających niejeden krwawy świt i wiele mrocznych dni. I tak, w tajemniczy sposób, smutna epoka Dymitriad znalazła swą paralelę ze światem mniej od nas odległym, mrocznym czasem radzieckiego rezimu zapoczątkowanym przez krwilwy świt rewolucji poprzedzony wystrzałem $z$ „Aurory”. 